\title{
Contemporary Challenges Confronting Islamic Banking \& Finance
}

\section{Muhammad Asif Khan ${ }^{1}$, Muhammad Waseem Shehzad², Muhammad Atif Khan ${ }^{3}$}

${ }^{1}$ Faculty of Commerce, University of Management Sciences and Information Technology, Kotli Azad Kashmir, Pakistan

${ }^{2}$ Faculty of Social Sciences and Humanities, University of Management Sciences and Information Technology, Kotli Azad Kashmir, Pakistan

${ }^{3}$ Faculty of Commerce, University of Management Sciences and Information Technology, Kotli Azad Kashmir, Pakistan

\section{E-mail address: atifqadeer86@gmail.com, khanasif82@gmail.com}

Keywords: Islamic banking and finance; Shariah; contemporary challenges

ABSTRACT. The philosophy of Islamic economics is "brining ecom ics an con once with Shariah", guiding Islamic banking and finance to abolish interest com op tions, as reported a monumental growth, envisaged the most lucrative and unsus ible segm 1 the economy. Islamic finance is undoubtedly flourishing worldwide entail traje v development but at other front it encounters a number of impediments in developm since its ception. The emphasis of this study is to encapsulate in tabular form, the cont mporary problen and challenges Islamic finance has encountered during the span of last 28-y rs from 1988 to 2015. The austere Shariah compliance; regulatory and prudential challenges; $n$ conception among western society about Islamic banking philosophy; unavailability of money an nital narket for scant Islamic financial instruments; piercing competition; privation mic bankmg and finance awareness; absence of uniform reporting standards; complexities of egu. ond supervisory issues; lack of central supervisory body, governance and dearth o consevsus among Shariah scholars been the precarious challenges among muthers. unified central regulatory and supervisory mechanism required in cony ring prinkled Islamic finance practices and to foster a synchronized and standardiz re consensus need to be developed among all Shariah scholars.

\section{INTRODUCTIPN}

The phi ophy Islamic economics is "brining economics in consonance with Shariah" guiding Islamı " k king d finance to abolish interest from operations, has reported a monume grow en isaged the most lucrative and unsusceptible segment of the economy. Islam ban ng emo d in 1963 in Egypt, currently operating successfully in above sixty corm w w mancial institutions offering wired range of Islamic products and services. Tscent islamic banking and finance has become a substantial challenge to firmly rooted western co ypart.

"Islamic finance is becoming an integral part of the global finance industry and has taken its roots in almost all of the Muslim countries but has also been under discussion and penetration in selective Western and Far Eastern jurisdictions"

\footnotetext{
${ }^{1}$ [M.Phil (Management Sciences), M.Com. (Finance)], serving as lecturer Commerce in department of Commerce since November 2006.

${ }^{2}$ MS Scholar, MSc Economics, serving as visiting lecturer at department of economics since 2013.

${ }^{3}$ MS Scholar and M.Com (Finance), serving as lecturer Commerce in department of Commerce since December 2013.
} 
Starting with modest beginnings nearly four decades ago, global Islamic finance has witnessed significant progress attracting both Muslims and non-Muslims clientele. With Middle East and Asia being the largest Islamic financial markets, many developed non-Muslim countries including USA, U.K, Korea, Luxembourg, Singapore and China are gradually recognizing Islamic finance as an alternate and viable financial system. Recent reports suggest that global Islamic banking assets are set to cross US\$1.8 trillion in $2013^{4}$.

Products offered by Islamic financial institutions range from commercial and investment banking, to takaful, mutual funds and capital markets. Sukuk in particular has proved to be a powerful tool in building the confidence of international investors in Islamic finance and has become an important tool for fulfilling public and private sector financing needs in a Shariabmpliant manner. Moreover, there are dedicated regulatory, accountings, Shariah and acade nic ins. ions at the global level that are providing support in establishing sound foundatic for the Is nic Financial System. The significant growth of Islamic finance is refletive incre sing acceptability of its merits and it is advancing towards globalization (SBP, 2013)

\section{Objective of the study}

Islamic finance is undoubtedly flourishing worldwide entails tâ, ory devely nent but at other front it encounters a number of impediments in developmeni ince nception. The emphasis of this study is to encapsulate the contemporary probl is and chally Islamic finance has encountered during the span of last 28 years from $198^{\prime}$ to 2015.

\section{KEY PROBLEMS AND CHALLENGES}

This section accounts for the schola antribution pertaining to key problems and challenges encountered by Islamic banking and fina last 28 years.

Unavailability of expertise pertaining to $1 \mathrm{~g}$ terh financing, lack of back-up institutional structures such as secondary coptra markets for Islamic financial instruments and strict compliance with the Shariah ry were the majo confronting issues to Islamic financial system (Ariff, 1988). The idea of slâ is quite viable but some critical factors in implementing at large sca are inado te institutional arrangements, lack of effective leadership and organization, intel $\mathrm{ct}$ resources sbilization through centers for learning (Siddiqi, 1989). Loss of Opportunitiss, Sharia aw's Admissibility in International Courts, Manpower Shortage, Undeveloped Int bank and Fina 1 Markets, Lack of Unified Accounting Standards for Islamic Banking are th key w knesses, handicaps and problems faced by Islamic banks (Pervez, 1990).

Myrin eco ists reed to change their focus. Instead of developing a theory in the frame ork an idea amic society, they should choose a contemporary economy and show, on the of anlife data, that the primary cause of existing economic problems lies in deviation from th amic principles of economic management. The economics that can grow with valid assumption adequate methodology and a body of economic theory capable of ushering in a humane socjety, would be the economics of the future (Khan, 1991). How to finance growth opportunities of a sole proprietorship Mudarabah, Musharaka or a hybrid enterprise? This question will remain as an important concern in Islamic finance Islamic finance confronts the challenge to devise Islamic financial instruments which can enable firms, sole proprietors in particular, to finance their growth without compromising on their ownership structures. In this regard, in addition to ownership sensitivities, retention and re-investment of profits is also worth mentioning (Ghazali, 1992).

\footnotetext{
${ }^{4}$ Ernst \& Young's World Islamic Banking Competitiveness Report 2013.
} 
The problem that Muslim countries face is even more difficult than that faced by the industrial countries; resources at their disposal are even scarcer. Removal of their macroeconomic and external imbalances requires a reduction in aggregate demand. Realization of the maqaid requires the opposite of this: increased spending for a number of neglected but essential objectives. How to resolve this conflict is the challenge that Muslim countries face. They cannot respond to this challenge successfully by adopting strategies that have failed. A failed strategy cannot but lead to failure. What the Muslim countries need to do is to develop their own strategy one that will help them allocate scarce resources efficiently and equitably in accordance with the demands of Shariah (Kuran, 1993). The study identified the following theoretical issues in Islamic banking: Examination of the permissibility of credit creation by banks from the Shariah point of view, Seigniorage (i.e., profits of money creation, its entitlement and distribution Disk and expectational characteristics of households, firms and banks in an interest free eco aomy, is of introducing negotiable papers in the Islamic financial market and the ways ontrolling hot money" movements in an Islamic framework of money and banking (Siddiqu

Social justice and equitable distribution of wealth and tax mon gitimate ownership, abolition of interest completely are among the macro $c^{1}$ lle. to Isla ic economy and financial system but there is a need to remove the misgivings orm west com nunity's mind regarding Islamic economics (BinSayeed, 1995). Islam $1 \mathrm{as}$ very $\mathrm{sp}$ ic approach to commercial transactions, the law of contract, interest cha res, hed to the very nature of property; this poses a variety of problems for Islamic oams. Work th different economic, financial, social, legal and religious environments, mplex Islamic concepts of banking, how impact upon the use of financial instruments, com1 rcial priori/es and services, relationships with central banks, comparative analysis of financial s ments ar the role of Islamic banking in a development context are the serious issues (41-Omar,

Findings establish that, in Singapore, w ich ilas minority of Muslims in its population, both Muslims and non-Muslims are oanerally u ware of the culture of Islamic banking. Also the two separate groups have differe it a ides to ards the Islamic banking movement, with the degree of difference dependin the hature of the respective matter put to them (Gerrard \& Cunningham, 1997). Build a per a moutional set-up, increased competition, building bridges and strategic alli ce, need crease the size of Islamic banks, financial engineering, Shariah aspects, teach hg, ining, res arch and development, fixed versus variable modes of finance, establishm of equit. struments, appropriate legal framework, policies and procedures and supervisory ramework are thaps the most serious challenges to Islamic finance (Iqbal, Ahmad \& Kh 1998

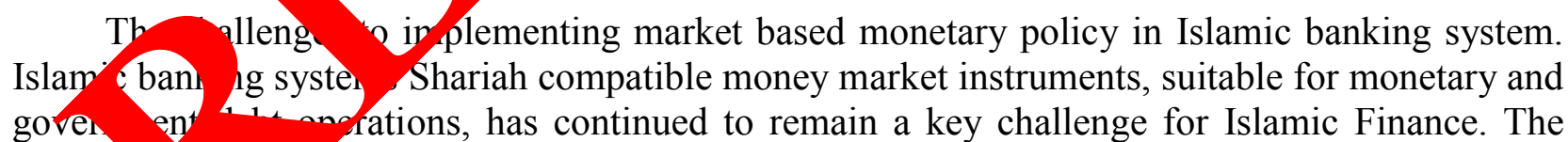
absence Islamic money markets continues to raise the liquidity risks of Islamic banks and weaken the fitability (Marston, Shabsigh \& Sundararajan, 1998). Islamic financial system is to become traly liquid and efficient it must develop more standardized and universally tradable financial instruments, the development of a secondary financial market for Islamic financial products, develop more transparency in financial reporting and accounting and ideally a form of Islamic GAAP, development of inter-bank and money markets (Sarker, 1999).

Technology is another challenge as Islamic banks are competing in a highly developed technological market that utilizes a wide range of sophisticated banking products. The problem is not only in the adoption of technology but in the preparation of a suitable environment that will enable them to utilize the technology in order to compete effectively. The globalization also imposes a challenge on the Shariah authorities in Islamic banks in the issuing of Fatawah required 
in the rapidly evolving international financial markets (Al-Raji, 1999). Regulatory complexities and branding of Islamic products are two prominent issues confronting Islamic financial institution in West and UK (Wilson, 1999).

Notwithstanding of Sharia compliance monetary policy for Islamic banks. Regulations for interest-based banking is equally applicable for the Islamic banks as in case of overdrawn funds from central bank interest required to be paid. No separate regulatory and supervisory guidelines for the Islamic banks. There are no Islamic financial Instruments developed for the Islamic banks to accommodate their excess liquidity or to provide them a new avenue for short term investment (Sarkar, 2000). A number of factors to be considered while confronting with conventional banking sector and an effective Islamic system facing the challenges like lack of financial markets in which Islamic financial instruments can be traded. The growth is closely tied wi the $\mathrm{m}$ e of novelty in the Islamic products and individual will choose these products ording to heir commercial needs as well as religious philosophy (Zaheer \& Hassan, 2001).

The provision and use of financial services and products that co form $t$ slamt eligious principles pose special challenges for the identification, measureme ring, a $\mathrm{l}$ control of underlying risks. Effective and efficient risk management is $I$ amic fin ial $j$ stitutions has assumed particular importance as they endeavour to cope w in challeng of globalization. This requires the development of not only a more suitab gula framework, but also new financial instruments and institutional arrangements to provide $1 /$ enabling operational environment for Islamic finance (Sundararajan \& Err o, 2002). The rofe of the state needs to be limited to that of a facilitator in matters of financial rvices. In p rticular, it needs to constantly monitor and upgrade the legal and regulatory environ $\mathrm{t}$ in whi h the industry operates without stifling independent initiatives or disorienting it through , poorly transparent changes. The state needs to refrain from becoming direct directly the promoter of financial activities where its presence is not essential for the pub ic gou imilarly, the population and businesses need to refrain from looking at the stota as the $b$ nevolent father, supplier of applause for success, and compensation for failure (Gra \& a ntur, 20 3).

Several challenges to mi niss roming to instruments, financial markets, regulations, clarity of its concepts an its awaren must be addressed and a viable solution must be found which is hindering th pro ss of Islo nic banks. Perhaps the most problematic aspect is the image and percepti fo Islan financial institutions in the global market (Nasim, 2003). It is apparent that the experience of $\mathrm{p}$ Kously established Islamic institutions, such as Al-Baraka, has made other in ution valize that it is possible to provide Islamic banking services in the UK under nonbanki gulatio. The interviews also revealed that the main problem that Islamic banking in $\mathrm{UK} / \mathrm{s}$ heterogeneous clients and potential clients. Moreover, regulatory hurdl s, co petition om conventional banks, and lack of adequately qualified and trained perso, o satuation (Karbhari, Naser \& Shahin, 2004). Fatwa is basically a religious ruling o, atter of Islamic laws not clearly mentioned in Shariah. Fatwa is required on those matters wh are uncertain in Islamic banking activities and are not in line with Shariah (Ali, 2005).

Serious challenge confronting to Islamic banking practitioners is an unresolved fiqh issue? A failure to realize maqasid al Shariah in a changing environment? In any case it requires stepping out of the current framework of thinking to face new realities and accommodate new priorities. Even from within the known techniques, there are some like mutuality whose potential for meeting this challenge has yet to be fully discussed and tried (Siddiqui, 2006). Risk management is one and at other front challenge concerns the diversity of opinion among Sharia scholars as to whether particular practices or products are Sharia-compliant. On a global level too, the 
ratification of Islamic firms' products and services may depend on the jurisdiction in which they are offered. This can add another layer of complications for regulators (Briault, 2007).

One important issue is that there is not a well-organized connectivity and network among Islamic FIs around the world and products offered are not homogenous. Such impediments may be removed to enlarge the processes and marketing strategies should be reframed to gauge international customers (Garas \& Manama, 2007). Regulatory amendments regarding structure of Islamic investment and financing and liquidity risk management. Lack of efficient and transparent capital markets, short-term Islamic money market, Islamic instruments, Islamic Financial Reporting Standards (IFRS), appropriate legal frameworks and regulatory disparity among national supervisors (Hesse, Jobst \& Sole, 2008). Lacking broad popular demand, lackmoulatory support by the state and lack experience in microfinance, Islamic rural bank, most absentee ownership; have failed to prove themselves as efficient and dyn ic provide of microfinance services (Seibel, 2008).

Key issues facing Shariah compliant banks trying to grow ty ir liqu ity mo agement products suite: Limited Islamic secondary markets, Various Shariah ter ations, s dall number of participants, Slow or stagnant development of Islamic financi instrum Co Amodities and inventory risk, Legal and Shariah compliance risk, Equity pos o $\mathrm{ck}$, Mark- 1 isk and Transfer risk (SunGard, 2008). The results of the research have led the clusion that besides other problems inadequate telecommunication infrastructure nas been fou the major problem in proper IT implementation in the Pakistani organizatior (Shaukat, Zafarulah \& Wajid, 2009).

Misconception against Islamic Banking, Lac f unifor hity between Shariah's view, Documentary complexity, moving towards mity-base $\mathrm{ng}$, Heightened Competition and Brand Recognition are serious issues facing Is anking (Samat, 2009). The challenges facing the regulators and supervisors of Islamic bank $\mathrm{g}$ e. lack of standard practices and different interpretation of same issue be Sharioh board each bank; market discipline and transparency and corporate governance issue ( $\mathrm{A}_{\mathrm{h}} \mathrm{d}, 201 \mathrm{l}$, The emerging institutions offering Islamic banking services; however is the challenge to regulatory and supervisory bodes as this challenge is different from ors. Is an challenge arises because of the methods these institutions adopt to mor ze funds a to deploy them to earn income on them. Among these assets management, sla banking contracts, protection of Islamic banks customers, transparency and presional npetition are prominent (Khan \& Porzio, 2010).

Liquidit isk is of the major challenges for Islamic banks in Pakistan and this study found insignifica ut posi e relationship of the networking capital ratio and bank size to LRM (liquidit mana nen and significant and positive association of CAR in conventional banks and $P$ OA it Islamic aks at 10 percent level (Sadaqat, Ali \& Farhan, 2011). There are three enorn the Islamic banks; 1) Compliance to Sharia while operating among the convent banking sector that has captured the maximum portion of market share by its organized a fiden network, 2) to cater the increasing need of industrial and business sector, and 3) to counter the embedded perception of Muslims that Islamic banking system is merely duplication of Interest-based system under the shade of Sharia (Hanif, 2011).

Islamic banking Industry is in need of transforming regulatory framework, risk and retail banking, so, the operations can be optimized and integrated with technology and mitigation of risk may be made possible (Ernst \& Young, 2012). There is no single authority that governs Islamic financial industry. There is no harmony among the Shariah scholars who give ruling about Islamic financial products. All the Islamic banks have their own Shariah Supervisory Board (SSB) who has knowledge of both finance and religion (Shah, Raza \& Khurshid, 2012). Stiff competition with deep rooted conventional banks and the promotion of distributional and allocating efficiency 
from all dimensions together with profitability are more challenging for Islamic banks in Bangladesh (Ullah \& Chowdhury, 2013).

To compete on a level playing field with other financial institutions, Islamic banks would need to be competitive and this means producing and having more innovative products that meet the demands of the individual and businesses. The Islamic products developed must comply not only with Shariah requirements but also with the country's legislation, guidelines and circulars. Corporate governance, supervision and monitoring the operations and performance of the Islamic banks are crucial in ensuring that banks carry the role to serve their client the Shariah way. Without proper regulations, policies and enforcement, the implication is normally transferred to the consumer (Aris, Othman, Azli, Sahri, Razak \& Rahman, 2013).

Although industry represents remarkable performance and liquidity $\mathrm{m}$ gement, has some challenges to be solved. Among others, there are three main challenge The challe ges is the market share of the industry which was 4.2 percent at the end of S ptember, 2 an lack of human resource and lack of product development are two other rdling he exp asion of industry (Ismal, 2013). The Shariah compliance is the backbone of Ts suring eir integrity and credibility. The existence of non-compliance element will no only affe he co sfidence level of IFI's shareholders and public but in addition to Shariah on mpliance and associated reputational risk may also expose IFIs to various other loss Karim Archer, 2013).

Lack of determination at the senior executive and managers, Lack of clear rules and adequate supervision, Lack of competitiveness with nventional 'anking system, Investors' risk aversion and the desire to get a fixed profit and Lack o fficient wareness among customers and people are significant challenges among othe (Seyed-Jan Laei, Safari \& Iravani, 2014).

The religious challenges found in this st y yo categories: Those that emanate from non-Muslim believers on one hand and that $\mathrm{m}$ ch are from within the boundaries of Islam on another hand. When non-Muslims misp ceived $t$ e institution to be battling against their religious dogmas, some Muslims also m. reeiy 2 it to b/ similar to the interest based system i.e. (not in line with the actual teachin of th narran, The mentioned challenges are regarded religious because of their direct lin ve with re vus belief (Yunusa \& Nordin, 2015).

\section{CONCLUSIO}

The mop oraph s contrived comprehensively the contemporary problems and challenges being faced by ac fina ye during last twenty eight years (1988-2015). The austere Shariah complian regu. $\mathrm{V}$ an prudential challenges; misconception among western society about Islami ban $\mathrm{g}$ philo ny; unavailability of money and capital market for scant Islamic financial inst hiercing Competition; privation of Islamic banking and finance awareness; absence of uniform ortmy standards; complexities of regulatory and supervisory issues; lack of central supervisor hody, governance; dearth of consensus among Shariah scholars; Lack of determinatio at the senior executives and managers; Lack of clear rules and adequate supervision; Lack of competitiveness with conventional banking system and misperception against the religious dogmas been the precarious challenges among many others.

\section{RECOMMENDATIONS}

Islamic banking and finance has a promising future hence, aforementioned issues mandate policy makers an objective religious zeal to grapple them. A unified central regulatory and supervisory mechanism required in converging sprinkled Islamic finance practices and to foster a synchronized and standardized regulatory framework consensus need to be developed among all Shariah scholars. 


\section{LIMITATIONS AND FUTURE RESEARCH}

The fundamental objective of this study was to highlight the contemporary challenges and problems Islamic banking and finance has been facing during 1988-2015. What would be the optimal mechanism to tackle the highlighted challenges and issues could be a prodigious extension to the study.

\section{References}

[1] State bank of Pakistan, Islamic banking bulletin (March, 2013), retrieved from

[2] Ariff, M. (1988). Islamic banking. Asian-Pacific Economic Literature, 2(2), 48-64. http://www.sbp.org.pk/ibd/bulletin/2013/IBB-March-2013.pdf

[3] Siddiqi, M. N. (1989). Islamizing economics. Toward Islamization of di lines, 25361.

[4] Pervez, I. A. (1990). Islamic finance. Arab Law Quarterly, 5(4), 259

[5] Khan, A. M. (1991). The future of Islamic economics. Futures, 2 (3), 24261

[6] Ghazali, A. (Ed.). (1992). An Introduction to Islamic Finang ?un blisher

[7] Kuran, T. (1993). Islam and the Economic Challenge. Is a Econom Series - 17

[8] Siddiqui, S. H. (1994). Islamic banking: genesi a ratio ev, evaluation \& review, prospects \& challenges. Royal Book Company.

[9] BinSayeed, K. (1995). Western dominance a political Islam: Challenge and response. SUNY Press.

[10] Al-Omar, F., Abdel-Haq, M., Fuac al-'Umar, od al-Haqq, M. (1996). Islamic banking: Theory, practice and challeng

[11] Gerrard, P., \& Cunningham, J. P. (19,7). Islamic banking: a study in Singapore. International Joy Bank tarketing, 15(6), 204-216.

[12] Iqbal, M., Ahmad, A. Kha T. (1990). Challenges facing Islamic banking. Islamic Development Bank, nic searumad Training Institute.

[13] Marston, D., S. Sundararajan, V. (1998). Monetary Operations and Government $\mathrm{K}$ bt $\mathrm{N}$ gement/Under Islamic Banking (EPub). International Monetary Fund.

[14] Sarker 4. A. (1999). Islamic banking in Bangladesh: performance, problems, and prospec. arnatio al Journal of Islamic Financial Services, 1(3), 15-36.

[15] in A. 1999). Islamic BanksTechnology and Global Challenges and Opportunities. Cent for Mid ne Eastern Studies, Harvard University, 177-178.

[16] Son, N.(1999). Challenges and opportunities for Islamic banking and finance in the Wo the United Kingdom experience. Thunderbird International Business Revis, w, 41(4-5), 421-444.

[17] Sarkar, A. A. (2000). Regulation of Islamic banking in Bangladesh: role of Bangladesh bank. International Journal of Islamic Financial Services, 2(1), 67.

[18] Zaher, T. S., \& Hassan, K. (2001). A comparative literature survey of Islamic finance and banking. Financial Markets, Institutions \& Instruments, 10 (4), 155-199.

[19] Sundararajan, V., \& Errico, L. (2002). Islamic financial institutions and products in the global financial system: key issues in risk management and challenges ahead (No. 20022192). International Monetary Fund. 
[20] Grais, W., \& Kantur, Z. (2003). The changing financial landscape: opportunities and challenges for the Middle East and North Africa. World Bank Policy Research Working Paper, (3050).

[21] Nasim, F. (2003). Prospects Of Islamic Banking: Legal and other Challenges and Issues.

[22] Karbhari, Y., Naser, K., \& Shahin, Z. (2004). Problems and challenges facing the Islamic banking system in the west: The case of the UK. Thunderbird International Business Review, 46(5), 521-543.

[23] Ali, (2005). Islamic Banking. Journal of Islamic Banking and finance, 4(1), 31-56.

[24] Siddiqi, M. N. (2006). Islamic banking and Finance in Theory and Practice: A Survey of the State of the Art. Islamic Economic Studies, 13(2), 1-48.

[25] Briault, C. (2007). London: centre of Islamic Finance?. Financial o ice Auth ity, [online]http://www.fsa.gov.uk/pages/Library/Communication/Speecb $/ 200$ 018_cb sht $\mathrm{ml}$ [Accessed 21st July 2013]

[26] Garas, S. N., \& Manama, B. A. (2007). Internationalizat of Asian ic/Financial Institutions: Challenges and Paths to Solution. Thun crovd arnatigal Business Review, 49(2), 225-249.

[27] Hesse, H., Jobst, A., \& Solé, J. (2008). Trends an Gallen ¿ in Islamic finance. World Economics, 9(2), 175-193.

[28] Seibel, H. D. (2008). Islamic microfinance Indonesia: the challenge of institutional diversity, regulation, and supervision. SOJOL N: Journa of Social Issues in Southeast Asia, 23(1), 86-103.

[29] SunGard. (2008). Islamic Banking Finance. Growth and Challenges Ahead. Downloaded from www.sungard.com/e bit on $/ 72013$.

[30] Shaukat, M., Zafarullah, M Jajid, R A. (2009). Information Technology in Pakistan: An Analysis of Probler s Fa d in In Implementation by Pakistan's Banking and

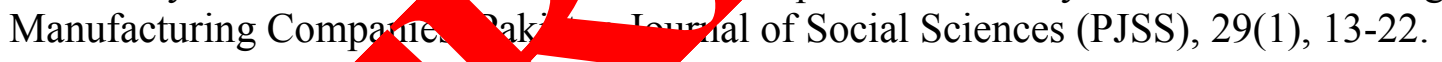

[31] Samat, D. S. Z. ( ( 09). Islan Banking: The Lessons and Challenges Strictly Private \& Confidential In la va \& Beyc a. Downloaded from www.bankis 1 com. con/documents/shariah/presentationtofstep-dsz.pdf

[32] Ahmed A. M E. T. (2 10). Islamic Banking: How to Manage Risk and Improve Profit ty $\left(\mathrm{y}_{0} 6^{4} 0\right)$. John Wiley \& Sons.

[33] Khan M. \& Po L10, M. (Eds.). (2010). Islamic Banking and Finance in the European Unt A Cha ge. Edward Elgar Publishing.

[34] Ali, K., \& Farhan M. (2011). Liquidity Risk Management: A comparative S. between Conventional and Islamic Banks of Pakistan. Interdisciplinary Journal of Res $Y$ in Business, 1(1), 35-44.

[35] Hanif, H. (2011). Differences and Similarities in Islamic and Conventional Banking. International Journal of Business and Social Science, 2(2), 166-175.

[36] Ernst \& Young, (2012). World Islamic Banking Competitiveness Report 2013 Growing Beyond DNA of Successful Transformation, retrieved from http://www.mifc.com/index.php?ch=151\&pg=735\&ac=818\&bb=file1

[37] Shah, F. S., Raza, M. W., \& Khurshid, M. R. (2012). Islamic Banking Controversies and Challenges. Interdisciplinary Journal of Contemporary Research in Business, 3(10), 1018 1026. 
[38] Ullah, M. M., \& Chowdhury, M. S. A. (2013). Prospects of Islamic Banking in Bangladesh. Proceedings of 3rd Asia-Pacific Business Research Conference, Kuala Lumpur, Malaysia.

[39] Aris, N. A., Othman, R., Azli, R. M., Sahri, M., Razak, D. A., \& Rahman, Z. A. (2013). Islamic Banking Products: Regulations, Issues and Challenges. Journal of Applied Business Research (JABR), 29(4), 1145-1156.

[40] Ismal, R. (2013). Islamic Banking in Indonesia: New Perspectives on Monetary and Financial Issues. Wiley. com.

[41] Karim, R. A. A., \& Archer, S. (2013). Islamic Finance: The New Regulatory Challenge. Wiley.

[42] Seyed-Javadin, S. R., Raei, R., Safari, M., \& Iravani, M. J. (2014). An ex anatory an sis to identify and prioritize the challenges of Islamic Banking implementatio he case IR Iran. International Letters of Social and Humanistic Sciences, (24), $50-35$.

[43] Yunusa, M., \& Nordin, N. B. (2015). Religious Challeng of Is curnic B rking in Nigeria. International Journal of Academic Research in Busi as à ocial S ences, 5(4), 46-66.

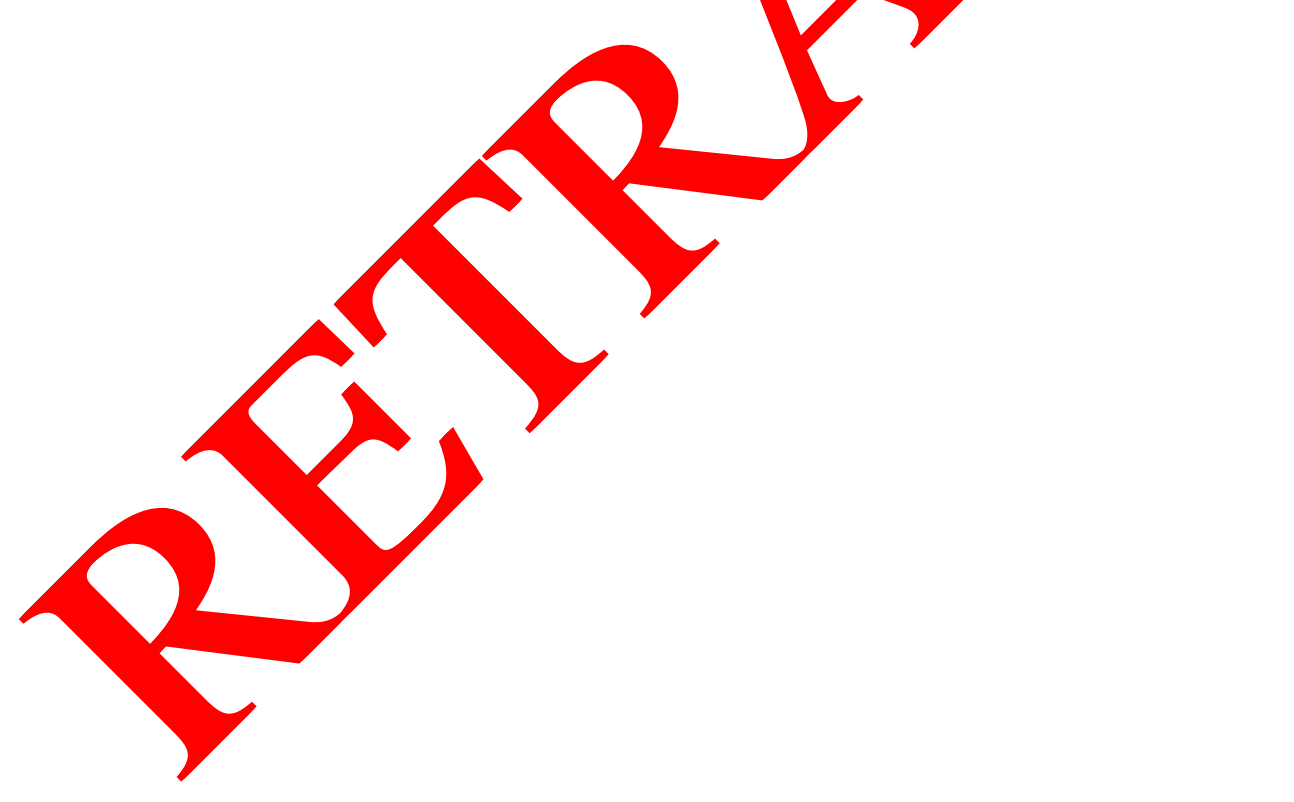

